\title{
PENGUATAN EKOSISTEM PEMBELAJARAN DIGITAL DIMASA PANDEMI COVID-19 MENGGUNAKAN APLIKASI EDMODO
}

\author{
Suryati $^{1}$, Sri Wahyuningsih ${ }^{2}$, Ramanata Disurya ${ }^{3}$, Ermini $^{4}$, Layang Sardana ${ }^{5}$, \\ Sri Husnulwati ${ }^{6}$, Jumroh ${ }^{7}$, M. Najib ${ }^{8}$, Sukardi ${ }^{9}$, Yenny Puspita ${ }^{10}$, Siti \\ Rukiyah $^{11}$ \\ 1,2,3,4,5,6,7,8,9,10,11 UniversitasPGRI Palembang \\ suryatilasnaimail.com, wsri7896@gmail.com, ramanatadisurya@gmail.com, \\ servaldae@gmail.com, layangsardana@gmail.com, srihusnulwati05@gmail.com, \\ jumroh.dahlan@gmail.com,mn760503@gmail.com, sukardipgri12@gmail.com, \\ yenny_puspitaa@yahoo.com, sitirukiyahpgri@gmail.com
}

\begin{abstract}
Abstrak
Pandemi Covid-19 telah merubah hampir semua bidang kehidupan masyarakat tidak terkecuali bidang pendidikan. Namun layaknya bidang lainnya, pendidikan segera berbenah dan menata diri menuju sebuah ekosistem bernama ekosistem digital. Sebagai sebuah aplikasi, Edmodo bisa menjadi sebuah pilihan untuk membantu mewujudkan hal tersebut. Tujuan dari tulisan dan pengabdian ini adalah memberikan gambaran bagaimana Edmodo dapat membantu proses belajar mengajar ditengah kondisi pandemi ini. Kegiatan ini berupa penyuluhan yang dilakukan pada guru di SMK Negeri Batu Marta, Kabupaten Ogan Komering Ulu (OKU) menggunakan liflet, infokus dan spiker. Hasil dari kegiatan ini adalah pengetahuan dan aplikasi 15 guru (75\%) tentang penggunaan aplikasi Edmodo menunjukkan baik. Pengetahuan yang baik. Pengetahuan aplikasi yang baik diharapkan dapat membantu para guru memberikan pengajaran yang optimal ditengah pandemi.
\end{abstract}

Kata kunci:Ekosistem, Pembelajaran Digital, Covid-19, Edmodo

\begin{abstract}
[Strengthening The Digital Learning Ecosystem During The Covid-19 Pandemic Using The Edmodo App]

The Covid-19 pandemic has changed almost all areas of people's life, including education. However, like any other field, education will immediately transform and organize itself into an ecosystem called the digital ecosystem. As an application, Edmodo can be an option to make this happen. The purpose of social service activity is to provide an overview of how Edmodo can help the teaching and learning process in the midst of this pandemic. This activity is in the form of counseling conducted to teachers at SMK Negeri Batu Marta, Ogan Komering Ulu (OKU) using leaflets, infocus and speakers. The results of this activity were the knowledge and application of 15 teachers (75\%) about the use of the Edmodo application showed the positive impact. Good ability in using technology is expected to provide optimal teaching in the midst of a pandemic for teachers.
\end{abstract}

Keywords:Ecosystem, Digital Learning, Covid-19, Edmodo

Artikel disetujui tanggal:30-05-2021

Corresponden Author:Suryati e-mail: suryatilasnaimail.com

DOI: http://dx.doi.org/10.31851/dedikasi.v4i1.5455 do 


\section{VAHANA DEDIKASI}

PENDAHULUAN

Kemajuan teknologi dan masyarakat informasi tidak bisa dihindarkan, yang mana semua bentuk komunikasi dan interaksi, baik dari sisi sosial maupun dunia bisnis, sudah berdasar teknologi. Kondisi ini membangun ekosistem yang sifatnya digital atau Digital Ecosystem (DE) yang secara langsung atau tidak langsung sudah memengaruhi pola kehidupan interaksi antarmanusia.

Ekosistem ialah semua yang ada dalam suatu wilayah dan saling memberikan dampak satu dengan lainnya pada wilayah tersebut (Cambridge dictionary). Digital Ecosystem (DE) ialah bentuk interaksi sosial melalui infrastruktur, seperti software, hardware, dan devices. Seseorang bisa berbagi informasi secara cepat dan melahirkan virtual community sebagai bentuk komunitas sosial yang muncul di dunia cyber (Cambridge, 2016).

Kemudahan akses informasi melalui berbagai media, web, e-mail, news group, dan lainnya membawa perubahan yang cepat juga dalam kehidupan antarmanusia. Manusia tetap sebagai kunci dalam ekosistem digital sehingga teknologi memberikan manfaat besar bagi jaringan sosial dan lingkungan virtual yang terbentuk. Konsep Digital Ecosystem (DE) yang relatif baru dan sangat multidisipliner harus dilihat dari berbagai sudut pandang atau perspektif. Secara umum, Wenbi Li (2012) mengatakan DE ialah komponen digital. Komponen digital merupakan ide yang diekspresikan melalui bahasa, digitalisasikan dan dikirimkan dalam suatu ekosistem yang bisa diproses manusia atau komputer (Perhumas, 2020).

Edmodo diciptakan oleh sebuah perusahaan ilmu pengetahuan dan teknologi bagi para penggiat pendidikan yang dapat dijadikan tempat untuk belajar bagi guru, peserta didik, dan orangtua. Edmodo berbentuk seperti social media sehingga sangat menarik untuk digunakan. Di dalam platform Edmodo ini baik pengajar maupun peserta didiknya dapat saling berinteraksi dengan mudah. Peserta didik, guru, dan orangtua dapat mengakses aplikasi ini dengan mudah yaitu dengan mendownload di playstore kemudian mendaftar.

Bagi guru, aplikasi ini sangat mendukung proses pembelajaran secara daring karena terdapat menumenu yang lengkap, mulai dari share materi dari berbagai sumber, pembagian tugas dan kuis yang dapat di akses secara online. Guru juga dapat langsung melakukan penilaian dengan cara memantau siswa yang sudah maupun belum menyelesaikan tugasnya. Manfaat bagi peserta didik, melalui Edmodo ini peserta didik dapat menyimak materi yang disampaikan oleh guru, kemudian mengecek tagihan-tagihan tugas dan kuis yang harus diselesaikan. Menggunakan aplikasi Edmodo sama halnya dengan menggunakan facebook. Layaknya sosial media bagi para pegiat pendidikan, Edmodo membantu peserta didik untuk berkomunikasi dengan peserta didik lainnya meskipun berbeda daerah bahkan negara. Selain guru dan peserta didik, orangtua peserta didik juga dapat menggunakan aplikasi Edmodo ini untuk meninjau 


\section{W/AHANA DEDIKASI}

perkembangan belajar peserta didik (Sarie, 2020).

Kegiatan ini dilaksanakan di SMK Negeri Batumarta. Secara umum para guru di sekolah ini masih banyak yang melaksanakan proses belajar mengajar pada masa pandemi ini dengan menggunakan bantuan aplikasi percakapan seperti Whatsapp (WA) dan e-mail. Hal ini tentu sangat terkait dengan pengetahuan yang kurang akan media pembelajaran berbasis aplikasi Edmodo, sehingga tujuan dari pengabdian masyarakat ini adalah untuk meningkatkan pengetahuan para guru di SMK Negeri Batumarta.

\section{BAHAN DAN METODE}

\section{a. Tahap Persiapan}

Tahap persiapan yang dilakukan pada kegiatan ini adalah mempersiapkan materi yang disampaikan melalui power point (infokus), dan leaflet. Alat-alat yang disiapkan untuk membantu penyiapan materi adalah layar, LCD dan laptop.

\section{b. Tahap Pelaksanaan}

Kegiatan ini dilaksanakan tanggal 9 April 2021 bertempat di SMK Negeri Batumarta. Metode yang digunakan dalam proses pengabdian kepada masyarakat ini berupa penyuluhan dengan metode semi-workshop disertai dengan tanya jawab.

\section{c. Evaluasi}

1. Evaluasi Struktur

Peserta yang hadir sejumlah 20 orang guru SMK Negeri Batumarta. Setting tempat sudah sesuai dengan rencana yang telah dibuat. Alat bantu penyampaian materi telah tersedia dan komunikasi yang dilakukan efektif sehingga materi dapat tersampaikan kepada peserta.

2. Evaluasi Proses

Kegiatan dilaksanakan sesuai jadwal yaitu pukul 08.00 11.30 WIB. Tempat pelatihan adalah berupa aula yang cukup.

3. Evaluasi Hasil

Evaluasi dilakukan dengan lembar presensi dan lembar evaluasi terkait pengetahuan para guru tentang aplikasi Edmodo. Evaluasi dengan menilaipeningkatanpengetahu an melalui post-test terkait materi.

\section{HASIL DAN PEMBAHASAN}

a. Hasil

Peserta kegiatan pengabdian kepada masyarakat ini adalah guru di SMK Negeri Batumarta sejumlah 20 orang guru.

Tabel 1. Distribusi Frekuensi Tingkat Pengetahuan Guru Tentang Aplikasi Edmodo

\begin{tabular}{lll} 
Tingkat & \multicolumn{2}{c}{ Post test } \\
\cline { 2 - 3 } Pengetahuan & F & \% \\
\hline Baik & 15 & 75 \\
\hline Cukup & 5 & 25 \\
\hline Total & 20 & 100 \\
\hline
\end{tabular}

\section{b. Pembahasan}

Pelaksanaan program pengabdian kepada masyarakat yang dilaksanakan pada 9 April 2021 berjalan dengan baik dan lancar. Pengabdian kepada masyarakat ini ditujukan kepada para guru di SMK Negeri Batumarta. MenurutSuhandiah(2019) para guru yang mengikuti penyuluhan atau diberikan informasi tentang informasi 


\section{W/AHANA DEDIKASI}

mengenai aplikasi terkait dengan pembelajaran atau media pembelajaran akan mengalami peningkatan pengetahuan. Hal yang sama terjadi pada para guru ketika diberikan penyuluhan tentang perkembangan penggunaan aplikasi berbasis Edmodo.

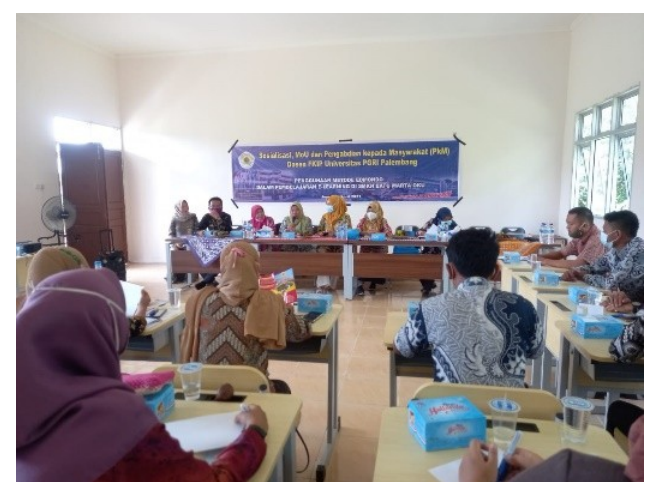

Gambar 1. Kegiatan Sosialisasi Aplikasi Edmodo di SMK Negeri Batumarta.

Dari hasil pengukuran melalui ost test didapat bahwa pengetahuan 15 guru (75\%) baik dan 5 orang guru (25\%) cukup setelah diberikan sosialisasi mengenai aplikasi pembelajaran berbasis Edmodo. Hal tersebut sejalan dengan hasil pengabdian masyarakat yang telah dilakukan oleh Sani (2020)yang menyatakan bahwa pemberian edukasi dapat meningkatkan pengetahuan para guru, khususmya pengetahuan mengenai bagaimana penggunaan aplikasi Edmodo dalam pembelajaran khususnya di masa pandemi Covid-19 seperti saat ini.

Pembelajaran E-Learning adalah pendekatan pembelajaran melalui perangkat komputer dalam bentuk PC, Laptop, Netbook, Tablet dan HP yang berbasis android, yang tersambung dengan internet, dimana siswa berupaya memperoleh bahan belajar yang sesuai dengan kebutuhannya. E-learning dapat dipandang sebagai suatu sistem yang dikembangkan dalam upaya peningkatan kualitas pembelajaran dengan berupaya menembus keterbatasan ruang dan waktu (Haris Budiman, 2014).

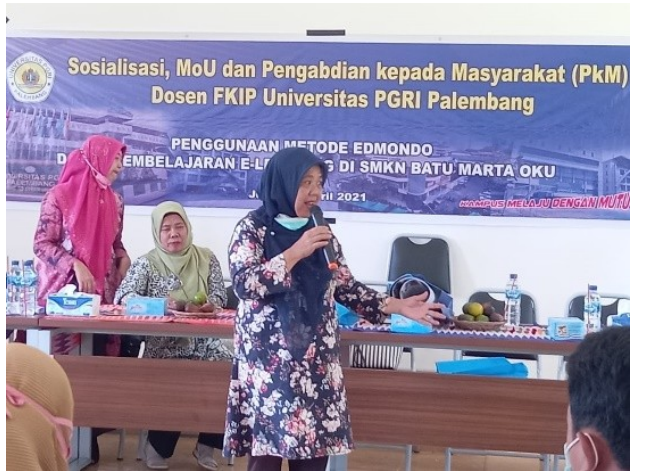

Gambar 2. Penyampaian Materi Aplikasi Edmodo di SMK Negeri Batumarta.

Pendidikan yang berkualitas tidak terlepas dari peranan guru dalam proses pembelajaran. Guru yang profesional akan menciptakan generasi masa depan yang memiliki sikap, pengetahuan dan keterampilan yang berkualitas. Untuk membentuk guru yang profesional diperlukan usaha-usaha untuk mengembangkan profesionalismenya. Salah satu usaha yang dapat dilakukan adalah dengan mengikuti pelatihan yang dapat meningkatkan kompetensi. Di zaman sekarang, guru dituntut untuk memiliki kecakapan digital (digital literacy). Oleh karena itu, guru harus mampu mengintegrasikan teknologi dalam pembelajaran. Untuk memfasilitasi hal tersebut, Universitas PGRI Palembang memberikan kesempatan kepada guru di SMK 


\section{WAHANA DEDIKASI}

Negeri Batumarta untuk mengikuti pelatihan Edmodo yang dapat meningkatkan kemampuan profesionalisme guru(Agustina \& Ratnawati, 2017).

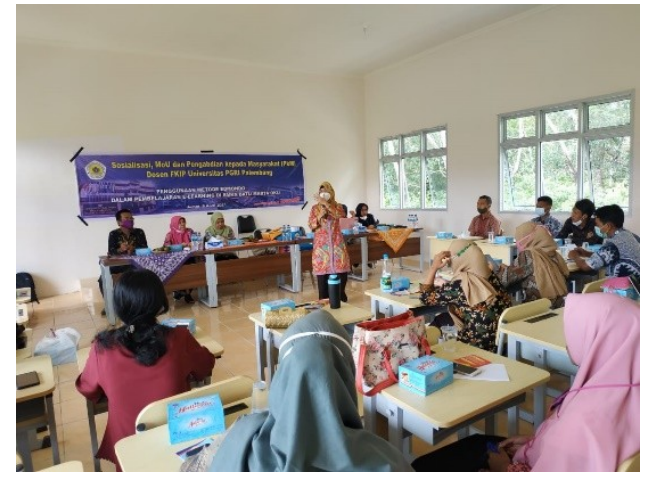

Gambar 3. Penyampaian Materi Aplikasi Edmodo di SMK Negeri Batumarta.

Pada dasarnya para guru di SMK Negeri Batumarta merasa sangat terbantu dengan adanya sosialisasi terkait media pembelajaran berbasis Edmodo yang dilakukan oleh dosen dari Universitas PGRI Palembang. Selama ini khususnya selama pandemi Covid-19, para guru hanya memanfaatkan media sosial seperti Whatsapp (WA) untuk mengajar sehingga masih satu arah. Edmodo sendiri adalah jejaring sosial dan layananmicroblogging yang di desain khusus untuk duniapendidikan, yang dapat dioperasikan sepertilayaknya Twitter. Dengan membatasi jalan akseske ruang khusus atau grup, guru dan siswa dapatsaling mengirim catatan, link, berkas,pengumuman, tugas dan bertukar informasi dilingkungan yang aman(Purnawarman, Susilawati, \& Sundayana, 2016).

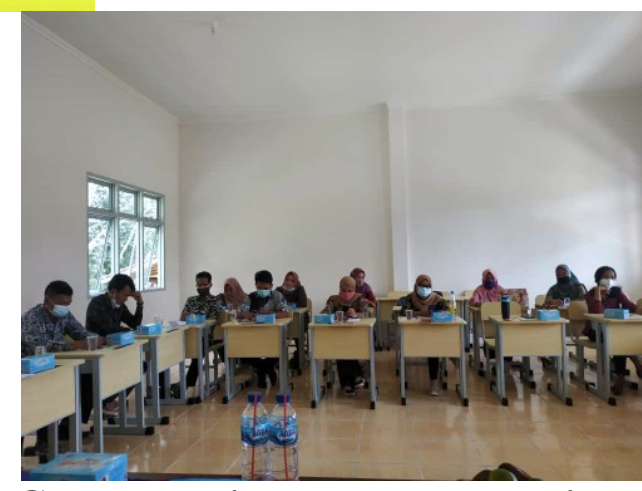

Gambar 4. Peserta Kegiatan Sosialisasi Aplikasi Edmodo di SMK Negeri Batumarta.

Edmodo juga dapat membantu guru yang tidakbisa mengajar di kelas dengan memberikan materipembelajaran secara online. Dalam Edmodo, Gurubisa memberikan tugas yang bisa ditentukan waktupengumpulannya serta meng-upload materipelajaran. Siswa juga bisa berbagi pemikiran atauide lewat posting-nya di Edmodo atau jikadisamakan dengan facebook, bisa dikatakanUpdate Status. Lebih tepatnya lagi, edmodo adalah"Facebook Guru dan Murid" karena fitur yangditawarkan hampir sama dengan facebook. Sepertidalam pembelajaran tatap muka, Edmodo jugamendukung model pembelajaran "team teaching". Guru dengan dapat mudah mengajak guru lainuntuk menjadi co-teacher. Kode parent samadengan kode yang diberikan kepada para siswa.Orang tua mempunyai hak akses untuk memantauperkembangan anak anaknya dan bisa jugaberdiskusi dengan guru(Alqahtani, 2019). 


\section{W/AHANA DEDIKASI}

KESIMPULAN

Merujuk pada hasil pelaksanaan pengabdian pada masyarakat di SMK Negeri Batumarta, maka dapat disimpulkan beberapa hal sebagai berikut :

1. Dari hasil pengukuran melalui post test didapat bahwa pengetahuan 15 guru $(75 \%)$ baik dan 5 orang guru (25\%) cukup setelah diberikan sosialisasi mengenai aplikasi pembelajaran berbasis Edmodo.

2. Pelaksanaan sosialisasi dengan metode semi-workshop masih jauh dari sempurna dan masih perlu perbaikan khususnya terkait waktu pelaksanaan.

3. Secara umum, para guru senang diberikan sosialisasi dan berharap di lain waktu dapat dilaksanakan kembali dengan durasi yang lebih lama.

\section{DAFTAR PUSTAKA}

Agustina, N., \& Ratnawati, S. (2017). Pengembangan Profesionalisme Guru Melalui Pelatihan Media Pembelajaran Berbasis Edmodo. Prosiding Seminar Nasional Pendidikan Teknik Informatika, Vol. 8.

Alqahtani, A. S. (2019). The use of edmodo: Its impact on learning and students' attitudes toward it. Journal of Information Technology Education: Research, 18. https://doi.org/10.28945/4389

Cambridge. (2016). Cambridge Dictionary.
Haris Budiman. (2014). Peran Teknologi Informasi Dan Komunikasi Dalam Pendidikan. Al-Tadzkiyyah: Jurnal Pendidikan Islam, 8(I).

Perhumas. (2020). Digital Ecosystem Suatu Keniscayaan PERHUMAS. Diambil 1 Maret 2021, dari https://www.perhumas.or.id/digit al-ecosystem-suatu-keniscayaan/

Purnawarman, P., Susilawati, \& Sundayana, W. (2016). The use of Edmodo in teaching writing in a blended learning setting. Indonesian Journal of Applied Linguistics, $5(2)$. https://doi.org/10.17509/ijal.v5i2 .1348

Sani, R. R., Utomo, D. W., \& Kurniawan, D. (2020). Penerapan Edmodo bagi Guru dan Murid SMK Karya Bhakti Brebes sebagai Media Belajar Tambahan. Abdimasku: Jurnal Pengabdian Masyarakat, 3(2). https://doi.org/10.33633/ja.v3i2. 92

Sarie, F. N. (2020). Optimalisasi Pembelajaran Daring Masa Pandemi Covid-19 Melalui Aplikasi Edmodo Bagi Siswa Sekolah Dasar. Tunas Nusantara. https://doi.org/10.34001/jtn.v2i2. 1497

Suhandiah, S., Sudarmaningtyas, P., \& Ayuningtyas, A. (2019). Pelatihan E-Learning Bagi Guru Untuk Optimalisasi Pembelajaran Generasi Z 
Suryati., dkk (2021)

Penguatan Ekosistem Pembelajaran Digital Dimasa Pandemi Covid19Menggunakan Aplikasi Edmodo

\section{WAHANA DEDIKASI}

Aksiologiya: Jurnal Pengabdian

Kepada Masyarakat, 4(1).

https://doi.org/10.30651/aks.v4i1

.3470 